\title{
Pitvarfibrilláció abláció szerepe szívelégtelen betegek kezelésében: fókuszban a CASTLE-AF-vizsgálat
}

\author{
Szegedi Nándor, Németh Tamás, Liptai Csilla, Nagy Anikó llona, Zima Endre, \\ Molnár Levente, Tahin Tamás, Széplaki Gábor, Merkely Béla, Gellér László
}

Semmelweis Egyetem, Városmajori Szív- és Érgyógyászati Klinika, Budapest

Levelezési cím: Dr. Szegedi Nándor, e-mail: szegedi.nandor@med.semmelweis-univ.hu

A pitvarfibrilláció a leggyakoribb tartós szívritmuszavar. Kezelésében az alapbetegség és társbetegségek gyógyítása mellett az antikoaguláció, a kamrai frekvencia kontrollja, illetve a sinusritmus helyreállítása és fenntartása lehet a célunk. Régóta ismert tény, hogy a ritmuskontroll elérésének leghatékonyabb módszere a katéteres abláció, ezzel azonban elsősorban a beteg életminőségének javulása érhető el, az ablációs terápia mortalitás csökkentő hatását eddigi nagy, randomizált vizsgálatok nem igazolták. A 2018 februárjában a New England Journal of Medicine-ben publikált „CASTLE-AF” vizsgálat egy prospektív, randomizált vizsgálat, amely az abláció primer végpontra kifejtett elönyös hatásán túl az összmortalitás csökkenését is kimutatta a gyógyszeres kezeléssel öszszehasonlítva, szívelégtelen betegekben. A kérdést, hogy az ablációnak valóban ilyen központi szerepet kell-e betöltenie a szívelégtelen pitvarfibrilláló betegek kezelésében, a jelenleg is zajló további randomizált vizsgálatok fogják megválaszolni.

Kulcsszavak: pitvarfibrilláció, abláció, szívelégtelenség, CASTLE-AF

Role of atrial fibrillation ablation in the treatment of heart failure patients: focus on CASTLE-AF trial Atrial fibrillation (AF) is the most frequent sustained cardiac arrhythmia. Therapy of AF should be based on treatment of underlying cardiovascular diseases, anticoagulation, rate and/or rhythm control. Catheter ablation of $A F$ is the most successful method for rhythm control however no randomized trial proved that it would improve patients' survival. "CASTLE-AF" trial was published recently in the New England Journal of Medicine. This prospective randomized study found that catheter ablation of atrial fibrillation improved the primary endpoint, moreover it also provided mortality benefit compared to the medical therapy in heart failure patients. It remains a question whether catheter ablation of atrial fibrillation will become a basic therapy of heart failure patients. Further ongoing trials are under investigation to answer this question.

Keywords: atrial fibrillation, ablation, heart failure, CASTLE-AF

\section{Pitvarfibrilláció elöfordulása, klinikai jelentősége}

A pitvarfibrilláció (PF) a leggyakoribb tartós ritmuszavar. Klinikai jelentőségét mutatja, hogy a pitvarfibrilláció fennállása a betegek halálozási kockázatát duplájára emeli. Kezelésében jelentős fejlődés történt az utóbbi 10 évben mind a stroke-prevenció, mind a ritmuskontroll terén. Prevalenciája a 20 évnél idősebb felnőtt populációban kb. 3\%, azonban előfordulási gyakorisága az életkor előrehaladtával emelkedik (65 év feletti populációban kb. 10-15\%). A betegség gyakrabban fordul elő férfiak esetén, valamint a fejlett országok lakosai körében. Egyes kórképek, úgymint a magasvérnyomás-betegség, szívelégtelenség, koszorúér-betegség, szívbillentyü-betegség, elhízás, cukorbetegség, illetve krónikus vesebetegség fennállása esetén szintén magasabb előfordulási gyakorisággal számolhatunk. A pitvarfibrilláció prevalenciája emelkedő tendenciát mutat, 
amelynek hátterében részben a diagnosztikus lehetöségek fejlődése, részben az magasabb várható élettartam és a kockázati tényezők gyakoribb előfordulása áll. Európában, 2030-ra kb. 14-17 millió pitvarfibrilláló beteget jósolnak, évente 120-250 ezer frissen diagnosztizált esettel (1-5).

\section{Pitvarfibrilláció ritmuskontroll terápiăja}

A katéterablációs terápia - nagy gyakorlattal bíró centrumban végezve - hatékonyabb a sinusritmus fenntartására, mint az antiaritmiás gyógyszeres kezelés: a transzkatéteres abláció átlagos sikeraránya (többszöri beavatkozás után) kb. 70\%, míg a gyógyszeres kezelés esetében ez általában $50 \%$ alatt marad (6-10). Ennek megfelelöen, a 2016-ban publikált European Society of Cardiology (ESC) irányelv alapján a tünetekkel járó paroxizmális és perzisztens PF esetén katéterablációs kezelés választható a tünetek csökkentése céljából, akár elsővonalbeli kezelésként is (11).

Jogosan merül fel a kérdés, hogy az ablációnak van-e létjogosultsága a szívelégtelen páciensek körében. A PABA-CHF randomizált, alacsony esetszámú klinikai vizsgálat 81 betegen vizsgálta az AV-csomó-abláció, illetve a pulmonalis vénaizoláció ( $\mathrm{PVI}$ ) egymáshoz viszonyított hatékonyságát. A PVI-csoportban 6 hónappal a beavatkozás után a páciensek $88 \%$-a volt ritmuszavarmentes, továbbá az életminőség javulása és az ejekciós frakció javulása is tapasztalható volt (12).

Az AFFIRM-vizsgálat post hoc analízise alapján felmerült, hogy a sinusritmus fenntartásával alacsonyabb lehet a betegek mortalitása (13). A DIAMOND-CHF (dofetilid-del végzett ritmuskontroll) study a sinusritmus fenntartásának előnyeit mutatta ki puha végpontok tekintetében (14). Más tanulmányokban szintén kimutatták a pitvarfibrilláló szívelégtelen betegek szisztolés balkamra-funkciójának, funkcionális kapacitásának és tüneteinek javulását ablációt követően $(15,16)$.

Az AATAC prospektív randomizált tanulmány 203 perzisztensen pitvarfibrilláló, szívelégtelen (NYHA II-III., $\mathrm{EF}<40 \%$ ) betegen vizsgálta az amiodaron és az abláció egymáshoz viszonyított hatékonyságát. Kétéves utánkövetés során a ritmuszavar-mentes betegek aránya magasabb volt az ablációs csoportban, és az életminőség javulása mellett az ejekciós frakció emelkedése itt is kimutatható volt. Ami pedig a vizsgálat talán legfontosabb eredménye, hogy az összhalálozás is szignifikánsan alacsonyabb volt az abláción átesett betegek között, mint az amiodaron terápiában részesült betegcsoportban $(8 \%$ vs. $18 \% p=0,037)(17)$.

A Városmajori Szív- és Érgyógyászati Klinikán pitvarfibrilláció miatt abláción átesett szívelégtelen ( $E F<40 \%)$ beteganyagunkban a beavatkozás 1 éves sikerarányát a nemzetközi adatokkal egybecsengően 70\%-nak találtuk, emellett a páciensek bal kamrai ejekciós frakciójának átlagosan 8\%-os növekedését figyeltük meg.

\section{CASTLE-AF-vizsgálat}

A fent leírtak alapján egyértelműnek túnik egy olyan nagyobb esetszámú, prospektív randomizált klinikai vizsgálat létjogosultsága, amely a pitvarfibrilláció abláció kemény végpontokra kifejtett hatékonyságát vizsgálja szívelégtelen páciensekben.

A „CASTLE-AF” egy prospektív, randomizált, kontrollált tanulmány, amelynek célja a pitvarfibrilláló, szívelégtelen betegekben a katéter abláció és a gyógyszeres kezelés hatékonyságának összehasonlítása volt. A vizsgálatba tünetes szívelégtelen betegek (NYHA II-IV.) kerültek bevonásra, csökkent szisztolés balkamra-funkcióval (EF $<35 \%$ ), akik paroxizmálisan vagy perzisztensen pitvarfibrilláltak. A páciensek Home Monitoring rendszerrel bíró ICD vagy CRT-D-készülékkel rendelkeztek, amelynek pitvari érzékelésre alkalmas elektródája is volt. A betegeket 1:1 arányban randomizálták ablációra, illetve gyógyszeres kezelésre. Az ablációs csoportban a beavatkozás célja a pulmonalis vénák izolációja volt, de az operatör döntése alapján kiegészítő ablációs vonalak alkalmazása is megengedett volt. A gyógyszeres csoportban is javasolt volt a sinusritmus fenntartására való törekvés. Abban az esetben, ha gyógyszeresen frekvenciakontroll mellett döntött a beteg kezelöorvosa, a cél frekvenciatartomány 60-80/perc volt nyugalomban és 90-115/perc mérsékelt terhelés alatt. Kontrollvizitek történtek 3., 6., 12., 24., 48. és a 60. hónapnál.

A vizsgálat primer kompozit végpontja a bármely okból bekövetkező halálozásból és a szívelégtelenség-progresszió miatti hospitalizációból tevődött össze. Szekunder végpontok voltak a bármely okból bekövetkező halálozás, a szívelégtelenség miatti hospitalizáció, a kardiovaszkuláris halálozás, cerebrovaszkuláris történés, illetve bármely okból történő hospitalizáció.

A vizsgálatba 363 beteget vontak be, ehhez a résztvevő magyar centrumok is jelentős mértékben (pl. a Városmajori Szív- és Érgyógyászati Klinika 28 pácienssel) járultak hozzá. Az ablációs csoportba randomizált betegek 98,7\%-ában végeztek sikeres pulmonalis vénaizolációt, illetve 51,7\%-ban történt addicionális léziók ablációja is. A gyógyszeres kezelésre randomizált páciensek között 30\%-ban alkalmaztak ritmuskontrolláló gyógyszert, $70 \%$-ban pedig csak frekvenciakontrollra törekedtek. Az utánkövetés időtartama $37 \pm 20$ hónap volt. Amennyiben ennek során 30 másodpercet meghaladó pitvarfibrillációt dokumentáltak, az ablációs csoportnak ismételt beavatkozást javasoltak, így az esetek 24,5\%-ában került sor második ablációra az utánkövetés során (az első beavatkozást követően $427 \pm 354$ nappal).

A kompozit primer végpont szignifikánsan kevesebbszer fordult elő az ablációs csoportban, a gyógyszeres csoporttal összehasonlítva (51 beteg [28,5\%] vs. 82 beteg $[44,6 \%] ; p=0,006)$. Szívelégtelenség miatti hospitalizáció szintén kevesebbszer fordult elő abláció esetén (20,7\% vs. $35,9 \%, p=0,004)$. A bal kamrai ejekciós frakció átlagosan $8 \%$-kal javult abláció esetén, míg csupán $0,2 \%$ - 
kal a gyógyszeres kezelés mellett $(p=0,005)$. A bármely okból bekövetkező halálozás $13,4 \%$ volt az ablációs csoportban, míg $25 \%$ a gyógyszeres csoportban $(p=0,01)$.

A CASTLE-AF-vizsgálat tehát relatíve nagy beteganyagon vizsgálta a katéterabláció kemény végpontokra kifejtett hatékonyságát szívelégtelen, pitvarfibrilláló betegek esetében. Az utánkövetés hosszú távon, megbízható módon történt Home Monitoring rendszerrel és pitvari érzékelő elektródával rendelkező ICD/CRT-D-készülék alkalmazásával. Tekintettel arra, hogy a korábbi vizsgálatok nem találtak érdemi különbséget a gyógyszeres ritmus-, illetve frekvenciakontroll hatékonysága között, jelen vizsgálat gyógyszeres ágán a beteg kezelőorvosa szabad kezet kapott a ritmus-, vagy frekvenciakontrolláló gyógyszer megválasztásában. A kompozit primer végpont tekintetében az abláció elönye már korán, 8-12 hónap után megnyilvánult, az összmortalitásra kifejtett jótékony hatása azonban csak hosszútávon, az utánkövetés 3. éve után jelentkezett. Ez a pozitív kimenetel független volt a szívelégtelenség etiológiájától (iszkémiás vs. nem iszkémiás), a készülék típusától (ICD vs. CRT-D) a pitvarfibrilláció típusától (paroxizmális vs. perzisztens). Kifejezettebb volt az abláció hatékonysága a 65 év alatti korosztályban, továbbá a diabetes mellitusban nem szenvedő pácienseknél, a kevésbé tünetes betegek (NYHA II. stádium) esetében, illetve ha EF >25\% volt. Fontos kiemelni továbbá, hogy a vizsgálat során a betegek pitvarfibrillációs „terheltsége” („AF bruden”, azaz a pitvarfibrilláció mellett eltöltött idő aránya) az ablációs csoportban kb. 25-30\%-kal volt kevesebb, mint a gyógyszeres csoportban. A fent leírt pozitiv hatások már a ritmuszavar előfordulási gyakoriságának csökkentésével elérhetők voltak. Ez azonban a CASTLE-AF eredménye alapján csak akkor igaz, ha a ritmuskontrollt antiaritmiás gyógyszer alkalmazása nélkül, tehát önmagában katéterablációval érjük el. Mivel a vizsgálatban résztvevő betegek többsége NYHA II-III. stádiumban volt, nem drasztikusan alacsony ejekciós frakcióval és nem régóta fennálló pitvarfibrillációval rendelkezett, így valószínüleg ezek a betegek profitálhatnak leginkább az ablációs kezelésből (18).

\section{Következtetések}

A jelenlegi ESC ajánlás a csökkent szisztolés balkamra-funkcióval bíró szívelégtelen páciensek tünetes pitvarfibrillációja esetén az ablációt megfontolandónak tartja, a tünetek csökkentése és a balkamra-funkció javítása céljából, azonban az irányelv egyelöre csak azokra az esetekre javasolja az abláció elvégzését, ha a szívelégtelenség hátterében tachycardiomyopathia valószínű (Ila indikációval, C-evidenciaszint mellett). A fent leírt klinikai vizsgálatok eredményének ismeretében a következő guideline már valószínủleg erősebb ajánlást fog megfogalmazni a szívelégtelen, pitvarfibrilláló betegek ablációjára vonatkozóan. További hasonló témájú, jelenleg is zajló klinikai vizsgálatok (pl. AMICA, EAST, OCEAN) alapján fog eldőlni, hogy a pitvarfibrilláció abláció a csökkent szisztolés balkamra-funkcióval rendelkező betegek kezelésének sarokkövévé növi-e ki magát.

\section{Irodalom}

1. Zoni-Berisso M, Lercari F, Carazza T, Domenicucci S. Epidemiology of atrial fibrillation: European perspective. Clin Epidemiol 2014; 6: 213220. doi: $10.2147 /$ CLEP.S47385

2. Bjorck S, Palaszewski B, Friberg L, Bergfeldt L. Atrial fibrillation, stroke risk, and warfarin therapy revisited: a population-based study. Stroke Nov 2013; 44: 3103-3108. doi: 10.1161/STROKEAHA.113.002329

3. Haim M, Hoshen M, Reges O, et al. Prospective national study of the prevalence, incidence, management and outcome of a large contemporary cohort of patients with incident non-valvular atrial fibrillation. J Am Heart Assoc Jan 21 2015; 4: e001486. doi: 10.1161/JAHA.114.001486 4. Benjamin EJ, Wolf PA, D'Agostino RB, et al. Impact of atrial fibrillation on the risk of death: the Framingham Heart Study. Circulation Sep 8 1998; 98: 946-952. doi: 10.1161/01.CIR.98.10.946

5. Stewart S, Hart CL, Hole DJ, McMurray JJ. A population-based study of the long-term risks associated with atrial fibrillation: 20-year follow-up of the Renfrew/Paisley study. Am J Med Oct 1 2002; 113: 359-364. doi: 10.1016/S0002-9343(02)01236-6

6. Calkins H, Reynolds MR, Spector P, et al. Treatment of atrial fibrillation with antiarrhythmic drugs or radiofrequency ablation: two systematic literature reviews and meta-analyses. Circ Arrhythm Electrophysiol Aug 2009; 2: 349-361. doi: 10.1161/CIRCEP.108.824789

7. Andrade JG, Khairy P, Macle L, et al. Incidence and significance of early recurrences of atrial fibrillation after cryoballoon ablation: insights from the multicenter Sustained Treatment of Paroxysmal Atrial Fibrillation (STOP AF) Trial. Circ Arrhythm Electrophysiol Feb 2014; 7: 69-75. doi: 10.1161/CIRCEP.113.000586

8. Nielsen JC, Johannessen A, Raatikainen P, et al. Investigators M-P. Long-term efficacy of catheter ablation as first-line therapy for paroxysmal atrial fibrillation: 5 -year outcome in a randomised clinical trial. Heart Mar 2017; 103: 368-376. doi: 10.1136/heartjnl-2016-309781

9. Pappone C, Vicedomini G, Augello G, et al. Radiofrequency catheter ablation and antiarrhythmic drug therapy: a prospective, randomized, 4-year follow-up trial: the APAF study. Circ Arrhythm Electrophysiol Dec 2011; 4: 808-814. doi: 10.1161/CIRCEP.111.966408

10. Kuck KH, Brugada J, Furnkranz A, et al. Cryoballoon or Radiofrequency Ablation for Paroxysmal Atrial Fibrillation. N Engl J Med Jun 9 2016; 374: 2235-2245. doi: 10.1056/NEJMoa1602014

11. Kirchhof P, Benussi S, Kotecha D, et al. 2016 ESC Guidelines for the management of atrial fibrillation developed in collaboration with EACTS. Eur Heart J Oct 7 2016; 37: 2893-2962. doi: 10.1093/eurheartj/ehw210 12. Khan $M N$, Jais $P$, Cummings $J$, et al. Pulmonary-vein isolation for atrial fibrillation in patients with heart failure. N Engl J Med Oct 23 2008; 359: 1778-1785. doi: 10.1056/NEJMoa0708234

13. Wyse DG, Waldo AL, DiMarco JP, et al. Atrial Fibrillation Follow-up Investigation of Rhythm Management I. A comparison of rate control and rhythm control in patients with atrial fibrillation. N Engl J Med Dec 5 2002; 347: 1825-1833.

14. Torp-Pedersen C, Moller M, Bloch-Thomsen PE, et al. Dofetilide in patients with congestive heart failure and left ventricular dysfunction. Danish Investigations of Arrhythmia and Mortality on Dofetilide Study Group. N Engl J Med Sep 16 1999; 341: 857-865. doi: 10.1056/ NEJM199909163411201

15. Cha YM, Wokhlu A, Asirvatham SJ, et al. Success of ablation for atrial fibrillation in isolated left ventricular diastolic dysfunction: a comparison to systolic dysfunction and normal ventricular function. Circ Arrhythm Electrophysiol Oct 2011; 4: 724-732. doi: 10.1161/CIRCEP.110.960690 16. Hunter RJ, Berriman TJ, Diab I, et al. A randomized controlled trial of catheter ablation versus medical treatment of atrial fibrillation in heart failure (the CAMTAF trial). Circ Arrhythm Electrophysiol Feb 2014; 7 : 31 38. doi: 10.1161/CIRCEP.113.000806

17. Di Biase L, Mohanty P, Mohanty S, et al. Ablation Versus Amiodarone for Treatment of Persistent Atrial Fibrillation in Patients With Congestive Heart Failure and an Implanted Device: Results From the AATAC Multicenter Randomized Trial. Circulation Apr 26 2016; 133: 1637-1644. doi: 10.1161/CIRCULATIONAHA.115.019406

18. Marrouche NF, Brachmann J, Andresen D, et al. Catheter Ablation for Atrial Fibrillation with Heart Failure. N Engl J Med Feb 1 2018; 378 : 417-427. doi: 10.1056/NEJMoa1707855 